\section{Opioid reduction strategies are important for laparotomies during the covid-19 outbreak}

To the Editor

The covid-19 pandemic has infected over 1.2 million people worldwide, with over 60000 deaths (at the time of writing). ${ }^{1}$ Presymptomatic transmission of the severe acute respiratory syndrome (SARS)-CoV-2 virus has also been reported. ${ }^{2}$ Anaesthesiologists are at high risk of perioperative viral transmission. Laparotomies, whether elective for malignancies or emergency, remain one of the essential surgeries that continue to be carried out. Based on the suggestion that HIV and human papillomavirus viruses can remain infectious and become dispersed in a plume of aerosolized smoke during laparoscopy, there is a possibility that the SARS-CoV-2 virus can too. There have been suggestions to shift to laparotomies for emergent conditions in untested or COVID-positive patients for safety reasons. ${ }^{3}$ The mainstay postoperative analgesia for patients after laparotomy in many centers is patient-controlled analgesia (PCA) with opioids. However in the current covid-19 pandemic situation, this poses potential infective risk as the pumps are difficult to be deep-cleaned and sterilized after one patient has finished using it. The SARS-CoV-2 virus has been shown to remain on plastic and stainless steel surfaces for up to 72 hours, ${ }^{4}$ and persons infected with it can shed and transmit the virus while asymptomatic. ${ }^{2}$ In addition, the acute pain service in many hospitals also requires patient contact during ward rounds to review the use of the PCA, posing yet another potential viral transmission risk.

Thus, for suspected or COVID-positive patients, the use of opioid-free anesthesia could help to reduce the use of both PCA and the need for patient contact while providing adequate analgesia for postlaparotomy patients. Our community is well versed in the use of non-opioid-based therapy and regional anesthesiology techniques that can optimize analgesia, reduce opioid use and promote positive respiratory outcomes. We think it is a critical time to advocate for such therapies. Phui Sze Angie Au Yong $\odot{ }^{1,2}$
Diana Xin Hui Chan

${ }^{1}$ Anaesthesiology and Perioperative Medicine, Singapore General Hospital, Singapore

${ }^{2}$ Anaesthesia, Sengkang General Hospital, Singapore

Correspondence to Dr Phui Sze Angie Au Yong, Anaesthesiology and Perioperative Medicine, Singapore General Hospital, 169608, Singapore; angie.au.yong.p.s@singhealth.com.sg

Contributors PSAAY: drafted and reviewed the final manuscript. DXHC: reviewed the final manuscript.

Funding The authors have not declared a specific grant for this research from any funding agency in the public, commercial or not-for-profit sectors.

Competing interests None declared.

Patient consent for publication Not required.

Provenance and peer review Not commissioned; internally peer reviewed.

This article is made freely available for use in accordance with BMJ's website terms and conditions for the duration of the covid-19 pandemic or until otherwise determined by BMJ. You may use, download and print the article for any lawful, non-commercial purpose (including text and data mining) provided that all copyright notices and trade marks are retained.

(C) American Society of Regional Anesthesia \& Pain Medicine 2021. No commercial re-use. See rights and permissions. Published by BMJ.

$$
\text { (D) Check for updates }
$$

To cite Au Yong PSA, Chan DXH. Reg Anesth Pain Med 2021;46:188.

Received 6 April 2020

Revised 9 April 2020

Accepted 13 April 2020

Published Online First 27 April 2020

Reg Anesth Pain Med 2021;46:188.

doi:10.1136/rapm-2020-101533
ORCID iD

Phui Sze Angie Au Yong http://orcid.org/0000-00029311-2532

\section{REFERENCES}

1 World Health Organization. World health organisation coronavirus (COVID-19) situation reports. Available: https://www.who.int/emergencies/diseases/novelcoronavirus-2019/situation-reports/ [Accessed Apr 2020].

2 Wei WE, Li Z, Chiew CJ, et al. Presymptomatic Transmission of SARS-CoV-2 - Singapore, January 23-March 16, 2020. MMWR Morb Mortal Wkly Rep 2020;69:411-5.

3 Cohen SL, Liu G, Abrao M, et al. Perspectives on surgery in the time of COVID-19: safety first. J Minim Invasive Gynecol 2020. doi:10.1016/j.jmig.2020.04.003. [Epub ahead of print: $03 \mathrm{Apr} 2020]$.

4 van Doremalen N, Bushmaker T, Morris DH, et al. Aerosol and surface stability of SARS-CoV-2 as compared with SARS-CoV-1. N Engl J Med 2020;382:1564-7. 